\title{
I Yacoubians hus
}

\section{En læsning af Alaa al-Aswanys arabiske roman Yacoubians hus med fokus på dens danske og internation- ale succes}

I artiklen "Den arabiske litteratur - endnu en antologi-litteratur" (Rannes 1992: 19) beklagede jeg først den halvdårlige modtagelse, som den ægyptiske litteraturs grand old man og Nobelprismodtager i litteratur, forfatteren Naguib Mahfouz' nyoversatte bøger da havde fået i Danmark. "Trods mange pæne ord var der flere steder en slet skjult skuffelse at registrere. Det mest rosende, der blev skrevet om Mahfouz' Midaqgyden, var, at den var sprællevende. Ellers lød dommen, at der var tale om nobelt håndværk og folkelig underholdning, og at romanen ikke overbeviste om Mahfouz' nobelprisformat", skrev jeg dengang.

Jeg var i artiklen dog grundlæggende optimistisk på den arabiske litteraturs vegne og mente, at denne ikke-europæiske litteratur, som Mahfouz repræsenterede, bl.a. byggede på helt andre fortælletraditioner end dem, vi kendte fra vores egen klassiske europæiske litteratur. Og at vi med oversættelsen af Mahfouz' bøger kunne møde denne nye litteratur i en form og på et kunstnerisk niveau, der gjorde det muligt for os at forstå og værdsætte denne litteraturs særegne kvaliteter: "Genlæser vi Naguib Mahfouz' romaner [...] vil vi kunne forstå den roste detaljerigdom som netop værende en del af den arabiske prosas bredde. Vi vil måske kunne forbinde og forstå sådanne litterære elementer 'bagom' vores egen diskursivitetsforståelse og opdage nye 'bredder' i denne litteratur. Måske vil vi endda opdage en litteratur, der ved sin bredde kan pille lidt ved de vestlige forestillinger om romanen som individets fortælling. Forudsat selvfølgelig, at formidlingen af den sker med sans og forkærlighed for dens bredde og dens andre litterære kvaliteter: Der er ingen smutveje ved at oversætte den fra engelsk eller andre sprog, kun den lange, lige vej er god nok" (Rannes 1992: 19).

10 år senere blev der lejlighed til at tage emnet op i et temanummer "Arabia" af det norske litteraturtidsskrift Vinduet. I artiklen "Tilfældet Naguib Mahfouz - eller gensyn med den arabiske litteratur" gik jeg bl.a. mere indgående ind i de danske anmeldelser af Mahfouz' bøger, men endte i samme konklusion. "Naguib Mahfouz er stadig kun hæderlig" citerede jeg en anmelder for at have skrevet (Rannes 2002: 
17). I farten fik jeg også slået fast, at "vi tager andre litteraturer til os for så vidt, at vi synes at kunne bruge dem. Eller rettere: Hvis de lever op til vores forventninger. Den latinamerikanske litteratur med sin fantasifulde magiske realisme kom nemt til os i 1980'erne, da vores egen litteratur var tørret ud i socialrealisme og bekendelseslitteratur" (Rannes 2002: 17). Jeg fortsatte: "Endda en slags arabisk litteratur er kommet til Vesten på den måde. Fransktalende og -skrivende arabiske forfattere fra Maghreb (Tunesien, Algeriet og Marokko) og Libanon skriver via Frankrig og fransk kultur gode og værdifulde romaner, som finder mange læsere og modtages godt overalt. Her finder vi den arabesk-agtige, labyrintiske verden, vi venter at finde i arabiske romaner [...], men at gøre dem til repræsentanter for en egentlig arabisk litteratur er en tilsnigelse" (Rannes 2002: 17f).

Jeg genlæste - stadig i artiklen i Vinduet - Mahfouz' roman Midaqgyden (1947, da: 1989), gengav henrykt romanens fantastiske (ikke-)plot og lagde an til en konklusion: "Mens jeg læser om alt dette i Midaqgyden, tænker jeg på den danske anmelders ord om, at den 'læser, der hos en Nobelprismodtager fra den 3. Verden forventer et eksotisk og mytepræget litterært univers, vil hos denne forfatter blive skuffet - eller måske glædeligt overrasket. For her er ingen komplicerede litterære strukturer eller mytedannelser.' Hvorfor egentlig savne 'komplicerede strukturer eller mytedannelser', når man har et plot, som det Midaqgyden tilbyder, når man har en historie med så mange enkelte elementer bundet sammen af én lokalitet, gyden, i en form, der får klassiske danske kollektivromaner til at fremstå som samlinger af individualistiske portrætter?” (Rannes 2002: 22).

Frustreret over hele situationen vrængede jeg "fjendebilledlitteratur" efter nogle af de arabiske prosaværker, som - trods alt - er nået frem til vores breddegrader: bl.a. værker af i Vesten så anerkendte forfattere som egyptiske Nawal El Saadawi og palæstinensiske Ghassan Kanafaani (nyere eksempler kunne være Miral al-Tahawis Den blå aubergine og Huda Barakats Silkekvindens sang). I en slags afmagt afsluttedes artiklen med denne efterskrift: "Det hænder ikke sjældent, at jeg spiller arabisk musik for venner og bekendte. Begejstret og opildnet prøver jeg at sætte dem ind i denne usædvanlige musiks storslåethed. [...] Som de gode venner, de er, lytter de. Prøver at forstå. Så siger de: 'Det er vist noget andet, når man selv har været der"' (Rannes 2002: 22).

Da jeg i mit arbejde og min hverdag var optaget af alt andet end arabisk litteratur, gik det i første omgang hen over mit hoved, at den ægyptiske forfatter Alaa alAswanys bog عمارة يعقوبيان (Imārat Ya'qūbīān, 2002) i efteråret 2007 forelå på dansk (oversat fra engelsk af Ingeborg Christensen) under titlen Yacoubians hus. I foråret 2008 fik jeg tag i bogen, læste den og så en slags håb forude. Som jeg skrev til Alaa al-Aswany, da jeg kort efter fors $\varnothing$ gte at invitere ham til at komme til Det Danske Forfatter- og Oversættercenter på Hald Hovedgaard: “Jeg synes virkelig om Deres bog. Den fyldte et hul eller en tomhed i mig, en mistro, som jeg havde haft siden den kulturelle dialog mellem Vesten og den islamiske verden (dvs. Mellemøsten) for nogen tid siden blev total smadret; måske allerede før 9/11 eller lige efter, det er ikke klart for mig. Min eneste følelse da var mismod - selv med mit kendskab til og fascination af den islamiske verden, var jeg ikke i stand til at forklare andre (eller mig selv for 
den sags skyld), hvad det hele dog gik ud på. Hvad handlede 9/11 dog om, hvad gik Golfkrigen ud på, og hvad var meningen med de idiotiske Muhammed-tegninger og med reaktionen på dem i den islamiske verden?"I

Men nu er der ikke noget at tage fejl af. Stablerne med hundredvis af eksemplarer af Yacoubians hus under skiltet med teksten "Trykt i mere end 75.000 eksemplarer i Danmark!" i bl.a. Bilka-varehusene og bogens stadige tilbagevenden til de danske bestsellerlister (selv efter at al-Aswanys nye bestseller Chicago er udkommet i Danmark $)^{3}$ er ikke til at tage fejl af. Den arabiske roman - eller i alt fald den egyptiske roman Yacoubians hus - er kommet til Danmark og har fundet et dansk publikum.

Yacoubians hus nævnes ofte i samme åndedrag som andre populære 'islamiske' romaner, f.eks. Khaled Hosseinis Drageløberen (The Kite Runner, 2003, da. 2003) og Kader Abdolahs Huset ved moskeen (Het huis van de moskee, 2005, da. 2008). Men til forskel fra disse er Alaa al-Aswanys roman skrevet på det sprog, den - så at sige - foregår på, ligesom den har haft et egentlig litterært liv i den kulturkreds, som den foregår i. Yacoubians hus er helt igennem en arabisk roman, den er skrevet på arabisk af en arabisk forfatter, der bor i den arabiske verden. Og så er den en arabisk roman, som er gået hen og blevet en international bestseller. Det er det, der gør den til noget særligt og gør den interessant i denne sammenhæng.

Yacoubians hus når, med sine gribende historier om en række nutidige egypteres store og små problemer, danske (og andre ikke-arabiske) læsere uden at være hverken fjendebilledlitteratur eller romantisk tusind-og-en-nat-agtig-litteratur. Romanens ligefremme tilgang til emner som f.eks. seksualitet (inkl. homoseksualitet), korruption, politivold, fundamentalisme og terror i den islamiske verden, der $\mathrm{i}$ alt fald siden 9/11 har sat sit tydelige præg på den internationale dagsorden, gør, at den når åbne og påvirkelige læsere (som jeg selv), der vil vide mere. Men er det virkelig nok til, at 90.000 danske læsere anskaffer sig denne roman af en ellers ukendt egyptisk forfatter?

Det mener jeg ikke. Yacoubians hus må fremvise nogle romanlitterære kvaliteter, som bevirker, at denne arabiske roman kan få så stort et internationalt og dansk gennembrud. Der må i romanens måde at være roman og fortælling på være noget, der lader den overskride de barrierer, som arabisk prosafiktion ellers hidtil har sat op mellem sig selv og ikke-arabiske læsere, noget som lader de nok så vedkommende fortællinger nå uhindret frem til læserne.

Som andre egentligt arabiske romaner bygger Yacoubians hus på den eksisterende moderne arabiske litteraturs prosa- og romantraditioner. Dette er en del af forfatterens forudsætninger (han kan godt have andre, han er uddannet i USA og behersker bl.a. engelsk så godt, at han har virket som oversætter af amerikansk litteratur til arabisk), og det er især de arabiske læseres forudsætninger og deres litterære horisont. Al-Aswany kan være lige så meget inspireret af vestlig litteratur, som han vil. Men som arabisk prosaforfatter, der vil nå - og når! det viser bestsellerstatussen - arabiske læsere, er han nødsaget til at skrive arabisk prosa. Det er stadig min påstand, at den arabiske prosa og prosafiktion ikke er som den vestlige. Det er også min påstand, at den enkelte prosalitteratur har en tilblivelseshistorie, der har præget den og er med til at karakterisere den. Og at prosalitteraturen i sit grund- 
udtryk ikke helt kan løsrive sig fra dette udgangspunkt. Den vestlige prosalitteratur udsprang af den oldfranske prosafortælling romanz og transformerede sig via bl.a. dagbog- og brevromanformen til en virkelighedsilluderende fiktion, der endnu den dag i dag - med eller uden olympisk fortæller - aldrig helt slipper sit tag i forestillingen om en bagvedliggende "virkelighed".

Den arabiske prosafiktion har også sin helt egen sprog- og litteraturhistoriske baggrund. To prosahistoriske karakteristika er påfaldende her: en svag, næsten manglende tradition for epik og prosalitteratur og et sprog, der synes at modarbejde det episke.

Den klassiske arabiske litteraturs historie er kendetegnet ved en sær bagudrettethed. Det skriftlige arabiske sprog, som blev konsolideret ved nedskrivningen af Koranen i det 7. århundrede, blev i før-islamisk tid til blandt ørkenbeduiner på Den Arabiske Halvø. Sproget var araberenes stolthed, og var stammen heldig - hed det sig - fostrede den en stor digter eller en stor kriger. Digterens digte var mundtlige, men sprogligt komplicerede. Som de sproglige forudsætninger for Koranens sprog, de var, fik de før-islamiske digte stor bevågenhed i den højtudviklede "litteratur" af videnskabelige grammatik- og fonetikstudier, som fra midten af det 8 . århundrede udvikledes i det nye, voksende islamiske rige, og af den grund er de bevaret $i$ tusindvis. ${ }^{4}$

Den arabiske litteraturs guldalder (750-1055) og sølvalder (1055-1258) producerede mængder af videnskabelig sagprosa og de oversættelser af klassisk græsk filosofi, som senere via Spanien nåede ud af glemslen og tilbage til Europa, hvor de inspirerede til den europæiske renæssance. Men den litterære digtning havde fokus rettet bagud mod den før-islamiske digtning, som den havde som ideal, og som den 'videreudviklede', og ved bl.a. khaliffernes hof digtede storbydigterne fortsat om den ensomme beduin i ørkenen.

Leder man, kan man i de gyldne perioder finde en slags episk prosa, Maqāma'en (maqāma $=$ forsamling eller møde), en rimet prosaform, hvor en eventyrlig og ikke særligt ærlig omrejsende hovedperson med stor sproglig virtuositet, beherskelse af den før-islamiske poesi og forståelse af filosofiske emner besnakker forsamlinger af tilhørere. I den arabiske litteratur kan Maqama-formen ses at spille samme rolle, som de folkelige romancer gør i den europæiske litteraturhistorie. De egyptiske forfattere fors $\varnothing$ gte i det 19. og 20 århundrede at samle denne klassiske prosaform op, men den var i løbet af de seks århundreders litterær stagnation, som fulgte sølvalderen, blevet efterlignet så tit, at den var endt som en tom sproglig kopi af den oprindelige Maqama. Her var ikke en moderne prosalitteraturtradition, der kunne bruges af det spirende moderne Egyptens forfattere.

Muhammad Ali Pasha, Egyptens osmanniske regent, etablerede i 1822 det første arabiske trykkeri i Kairo bl.a. for at lade europæiske faglitterære værker oversætte og udgive på arabisk. Den nationale (egyptiske og arabiske) bevidstgørelse, som fulgte Pasha'ens bestræbelser på at føje et moderniseret Egypten til Europa, igangsatte den arabiske kultur og litteraturs renæssance. Den nye tids digtere fandt først inspiration i Guld- og Sølvalderens litteratur, men som nationalbevidstheden tog til, forskød inspirationen sig atter bagud til den før-islamiske digtning. Her fandt 
digterne det rene arabiske sprog, der var brug for i genskabelsen af et brugbart indholdsfyldt (også prosa-) litterært sprog efter de mange århundreders sproglige stagnation. Den første arabiske avis blev etableret i Kairo i 1828, og avismediet, der hurtigt spredte sig til andre arabiske lande, fik en afgørende rolle i udviklingen af et brugbart skriftsprog. Formidlingen af dag-til-dag-nyheder krævede et enklere skriftsprog, end der umiddelbart var til rådighed. Resultat blev det skriftsprog, der siden er blevet til det fælles-arabiske skriftsprog "Modern Standard Arabic".

Da den begyndende modernisering af det egyptiske (og andre arabiske) samfund i slutningen af det 19. århundrede fordrede en moderne arabisk prosalitteratur, som kunne rumme og udtrykke det enkelte individs nye modernistiske bevidsthed (Watt 1957), blev inspiration hentet i den europæiske prosatradition. Franske og engelske romaner blev 'oversat' fuldstændigt til arabisk og arabiske forhold, således at hovedpersonerne fik arabiske navne, og handlingen blev henlagt til arabiske lokaliteter. Tidlige prosalitterære pionerer var bl.a. Abdallah Fikri (1834-90), hvis Breve (rasā'il) skaffede den litterære prosa fornyet prestige, og Jurji Zaydan (18611914), der inspireret af Alexander Dumas og Walter Scott skrev en række historiske 'romaner'.

Arabiske og vestlige litteraturhistorikere er dog enige om, at man skal ind i det 20. århundrede, før der kan tales om et egentligt arabisk prosagennembrud med Muhammad Husayn Haykals (1888-1956) roman Zaynab (1913), der dog var en enlig svale. 20'erne og 30'erne bød på masser af prosa i novelleform, men først i slutningen af 30'erne bliver romanformen rigtigt samlet op igen. I 1938 udgav Abbās al-'Aqqād (1889-1964) romanen Sarah, og i 1939 udgav både Ibrahim al-Mazini (1890-1949) romanen Ibrähīm al-Katiāb og førnævnte Naguib Mahfouz (1911-2006) sin debutroman Abath al-Aqdar. Selvom Mahfouz' produktivitet var en del over gennemsnittet - fra 1939 til 1988 udgav han 45 prosabøger (hovedsagelig romaner) var den dog betegnende for, at der nu var kommet gang i den arabiske roman.

De kvaler, den arabiske litteratur havde med at få etableret en egentlig prosatradition og holde liv i den, skyldtes ud over de manglende episke litterære traditioner og et manglende brugbart prosasprog et relateret problem: det arabiske sprog selv. Det arabiske sprog er syntaktisk karakteriseret ved, at de enkelte sætninger i sætningskonstruktionen er sideordnede frem for underordnede (som f.eks. på dansk og andre indoeuropæiske sprog). Samtidig opererer arabisk, der principielt kun har to verbaltider, ikke med "datid" og "nutid" i den forstand, vi kender det, men med "perfektum" og "imperfektum", der indikerer hhv. afsluttethed og uafsluttethed. Disse og andre sproglige forhold betyder, at det tidsforløb, som den arabiske tekst er i stand til at udtrykke, er mere uklart og utydeligt end i tilsvarende indoeuropæiske tekster. ${ }^{5}$ En tekst med ingen eller kun svage tilkendegivelser af tidsforløb mangler umiddelbart de episke elementer, som skal til for at holde en lang prosatekst som romanen i gang. Man kan ligefrem mene, at det arabiske sprog i sig selv modarbejdede den lange episke prosalitterære form. De arabiske prosaforfatteres umiddelbare håndtering af dette problem var at skrive kort, og således blev novelleformen tidligt den moderne arabiske litteraturs foretrukne prosaform. ${ }^{6}$ De romaner, der trods alt blev skrevet, var tit forholdsvis korte, gik formmæssigt i bredden og fremviste en slags 'tøven' i handlingsforløbet, der bevægede sig mere ud til siderne 
end fremefter. Formelt kunne det gøres ved f.eks. at lade romanen blive fortalt fra flere forskellige synsvinkler.7 En anden løsning var at vælge kollektivromanformen, hvilket ofte er tilfældet hos Naguib Mahfouz, og som Alaa al-Aswany gør det i Yacoubians hus. ${ }^{8}$

Titlen Yacoubians hus henviser til en 10 etagers bygning, der i romanen (og i virkeligheden, hvis det interesserer nogen) er bygget i centrum af 1930ernes Kairo. Foruden at være den ramme, som hele romanen er bygget op over, er Yacoubians hus i det små også en inkarnation af Egyptens nyere historie. Det starter med, at "[den] tids øverste samfundslag flyttede ind i Yacoubians hus - ministre, bashaer med store jordbesiddelser, udenlandske fabrikanter og to jødiske millionærer" (alAswany 2007, 18). Så kom "Revolutionen [1952], og alt ændrede sig. Jøderne og udlændingenes udgang af Egypten begyndte, og alle lejligheder som blev ledige på grund af ejernes udrejse, blev overtaget af hærens officerer, som var dem der fik indflydelse på det tidspunkt" (18f), hvilket bl.a. betød, at nogle særlige "jernværelser' på husets flade tag, der før kun havde været brugt til opbevaring og tøjvask, for første gang blev "[...] brugt som værelser for hushovmestre, kokke og unge tjenestepiger som [officersfruerne] hentede ind fra landsbyerne" (19). I 70'erne "kom 'den åbne dørs politik', og de velhavende begyndte at forlade den indre by for at flytte til al-Mohandesin og Medinet Nasr. Nogle af dem solgte deres lejligheder i Yacoubians hus, andre brugte dem som kontorer og klinikker for deres sønner, som havde fået en universitetsuddannelse" (19), og forbindelsen mellem lejlighederne og jernværelserne på taget forsvinder: "Det endelige resultat blev en stærk vækst i et helt nyt samfund på taget, som var helt uafhængigt af resten af huset. Nogle af de nytilkomne lejede to værelser ved siden af hinanden og indrettede en lille bolig der med både latrin og vaskerum [...] og sådan kom tagsamfundet til at ligne ethvert andet kvarter i Egypten" (20).

Forfatteren Alaa al-Aswany, der som tandlæge i en årrække har haft klinik og sin daglige gang i virkelighedens Yacoubians hus, har lagt sin roman i munden på en alvidende fortæller, der synes at befinde sig midt blandt sine hovedpersoner: "Zaki Bey al-Dessouki er noget af en original, og det gør at man både ser frem til at han kommer på gaden, og at han virker fuldstændig uvirkelig, som om han kunne forsvinde hvad øjeblik det skulle være" (9f.). Fortælleren er dog sin fortællerrolle bevidst: "Nogle vigtige oplysninger om Zaki Bey al-Dessouki skal gives her" (10). Han ved, hvad hovedpersonerne føler: "Hans følelser svingede mellem stigende utålmodighed efter det dejlige møde og ængstelig tvivl om hvorvidt hans dejlige Rabab nu også ville møde op" (15). Men fortælleren giver samtidig afkald på at vide alt: "De oplysninger der er tilgængelige om Abaskharon i hans ungdom er uhyre mangelfulde" (30), og han kunne da for den sags skyld være en af beboerne i Yacoubians hus, hvilket også er det overordnede indtryk fortælleren, efterlader.

Romanen er formet som en kollektivroman, hvis mange forskellige personer alle har tilknytning til bygningen Yacoubians hus. Centralt i handlingen er Zaki Bey el Dessouki, en ældre, rig levemand, der tvinges ud af den lejlighed, han deler med sin magtsyge søster. Han søger tilflugt i sit kontor i Yacoubians hus, som søsteren imidlertid også efterstræber ham. Den unge mand Taha el Shazli er søn af husets bawab 
(dørmand) og ansøger til politiskolen, hvor han afvises alene pga. farens job. Han indskrives i stedet på Kairo Universitet og rekrutteres der af en yderligtgående islamisk organisation og ender som offer for grov politivold og som terrorist. Busayna el Sayed er Tahas ungdomskæreste og husets (dvs. tagets) skønhed, der for at understøtte sin familie efter farens død må lægge krop (dvs. kjole) til sin arbejdsgivers seksuelle excesser. Hun bliver siden Zaki Beys 'assistent' og hans hustru. Hatim Rasheed er chefredaktør på det fransksprogede dagblad "Le Caire" og praktiserende homoseksuel. Han holder - og prøver at fastholde - Abduh, en ung smuk, men heteroseksuel og gift øvreegypter, som sin elsker. Hajj Azzam, der ved salg af tøj og biler (og narko) på 30 år har taget vejen fra skopudser til selvgjort millionær, 'engagerer' og indsætter pga. sin voksende libido en (hemmelig) andenhustru i en lejlighed i Yacoubians hus og køber sig vej til parlamentets andetkammer. Endelig kan nævnes Malak Khilla, en grådig skjorteskrædder, som rykker ind på taget af Yacoubians hus, og som via Busayna arbejder på at få neglene i Zaki Beys kontorlejlighed.

I løbet af de første 60 sider bliver romanens hovedpersoner og deres særlige 'skæbne' præsenteret en efter en i det, der ligner fortælleforløbets egen kronologi. Derefter holder fortælleren de forskellige historier sideløbende i gang - stadig uden nogen væsentlige indikationer af den indbyrdes kronologi - ved at fortællingen glider videre, eller ved at der klippes fra en historie til en anden. Generelt er tidsaspektet i romanen ganske svagt. Der er enkelte angivelser af tiden inden for de enkelte historier som f.eks. "Da vinteren kom" (161) og "Igennem to måneder" (178), men ellers er det angivelser som "næste dag" eller endda fortælletekniske klodsede løsninger som "Denne samtale havde fundet sted dagen før" (199). Selv for den analyserende læser er det ikke helt klart, hvor langt et tidsrum romanens handling (handlinger) udspiller sig over. De enkelte historier har deres eget, utydelige tidsforløb, men det eneste fælles tidsforløb er fortællingens egen, dvs. den rækkefølge de enkelte dele af de forskellige historier fortælles i.

Der er i romanens mange umiddelbare parallelle, men uafhængige historier kun et eneste tidsligt krydspunkt. Det findes i overgangen mellem romanens eksplicit angivne første og anden del (114). ${ }^{9}$ Her foranlediger den ærgerrige skjorteskrædder Malak - for egen vindings skyld og via sin etbenede bror Abashkaron, der er Zaki Beys tjener - at taglandsbyens skønhed Busayna bliver ansat som Zaki Beys personlige assistent.

Busaynas "nedstigning" fra taget til Zakis levemandskontorlejlighed - en begivenhed, der ved det endelige giftermål med Zaki bliver en social opstigning - er således fortælleteknisk romanens nøglebegivenhed. Men ikke nok med det. I overgangen fra romanens 1 . del til den 2 . del fungerer denne begivenhed også som det 'hængsel', hvorom hele romanen er vinklet og bevæger sig. Overgangen her er ikke kun et indholdsmæssigt 'skæbne-hængsel' i Busayna-Zaki-historierne, men er også et fælles omdrejningspunkt for alle kollektivromanens andre historier. Alle romanens bi- og hovedpersoner får deres skæbne beseglet hen over dette punkt i romanen. Fra første til anden del af romanen bliver Taha til fundamentalist, Hajj Azzam bliver valgt ind i parlamentet, mens hans andenhustru Souad afslører, at hun er gravid. Homoseksuelle Hatim får her etableret sit forhold til sin øvreegyptiske elsker Abduh, som for sin part bliver installeret som kioskejer i Kairo med hustru og 
barn. Den eneste person, hvis livsbane og skæbne ikke bøjes og formes her, er skjorteskrædderen Malak, skæbnemageren selv. På et indholdsanalytisk plan kunne man evt. hæfte sig ved, at den der styres af grådigheden - den grådighed, der ifølge alAswany styrer Egypten? - påvirker alle andres skæbne, men ikke sin egen.

Fortællingen om den ældre, europæisk skolede Zaki Bey Dessouki og den unge ærke-egyptiske Busayna er således både formmæssigt og indholdsmæssigt romanens ramme- og nøglehistorie, en position, der styrkes af, at den også er en del af historien om Yacoubians hus selv. Zaki Bey, der er repræsentant for den kultur, der byggede huset i 1934, bliver gift med Busayna, den yngste generation, som kommer fra et af jernværelserne på taget. Ægteskabet, som ved romanens slutning på handlingsplanet sikrer, at Zaki Beys søster ikke arver den ellers ugifte og barnløse levemand, har også indlysende symbolsk karakter. Det gamle europæisk-inspirerede Egypten fra før 1952-revolutionen forenes med det nye, ikke-islamiske Egypten, og det giver en happy ending. Pointen skæres helt ud i pap ved romanens afslutningsscene. Gæsterne ved brylluppet er hovedsagelig folk fra taget af Yacoubians hus, men rammerne er madame Christines 'europæiske' restaurant Maxim. Det er ikke et helt problemfrit møde: "I samme øjeblik bruden kom til syne, rørte synet af hende dem alle om hjertet, og en tydelig og hæmningsløs storm af melodiøse, gentagne jubelhyl brød ud. Alle var glade, og så snart orkestret var færdig med bryllupsmarchen, og buffeten var blevet åbnet, gjorde Christine et fors $\varnothing \mathrm{g}$ på at holde fast i den europæiske stil i festen ved at spille Edith Piafs "La vie en rose" på klaveret" (al-Aswany 2007, 254f). På det indholdsanalytiske plan er der masser af fed symbolik at lege med, hvis man vil det. På romanens fortællemæssige plan kan den vægtige afslutning gøre det ud for én fælles afslutning på romanens mange forskellige - og indholdsmæssigt uafhængige - historier.

Konklusionen af den fortælletekniske analyse af Yacoubians hus er, at romanen - til trods for, at den er en 'rigtig' arabisk roman - fremviser en række fortællemæssige og prosalitterære karaktertræk, der appellerer til såvel arabiske som ikke-arabiske læsere, og som muliggør bogens internationale udbredelse. Det er ikke romanens fortælletekniske karaktertræk i sig selv, der bevirker bogens internationale succespotentiale. Men dens fortælletekniske boniteter lader de særdeles vedkommende og aktuelle historier, som gjorde bogen til en succes i den arabiske verden, nå et læsepublikum med andre fiktionsvaner og -traditioner.

Med henvisning til den arabiske romans historie og litteraturhistoriske forudsætninger fremførte jeg ovenfor, at den fortælle- og formmæssigt går i bredden i stedet for i længden som sit europæiske forbillede. Det er i høj grad også tilfældet med Yacoubians hus, der er en typisk arabisk kollektivroman, som f.eks. Mahfouz' roman Midaqgyden, en bog, der i øvrigt meget vel kunne være al-Aswanys litterære forbillede. Yacoubians hus fremviser både i kollektivromanformen og i den måde, de enkelte historier inden for formen er forbundne, den fortællemæssige horisontalitet, der lader fortællingen brede sig ud til siden, væk fra f.eks. en enkelt individualistisk hovedperson. Vi ser bl.a., hvordan al-Aswany lader de enkelte historier løbe parallelt uden nogen form for intern eller fælles tidsangivelse. Den brede arabiske fortælleform kan f.eks. horisontalt beskrive de indbyrdes forhold mellem et per- 
songalleris forskellige typer og derved fortælleteknisk formå at definere de enkelte personer ved deres placering $i$ en helhed, i et samfund, i det hus en vis armensk rigmand, Yacoubian, byggede i 1930'erne. Eller i en lille Kairo-gyde, der kaldes Midaqgyden.

Det er i forlængelse heraf, at den arabiske roman, når den er bedst, er i stand til at præsentere europæiske læsere for en fortællemæssig bredde og en ikke-diskursivitet, som vi ikke kender i nogen form fra vores egen prosalitteratur. I artiklen i tidsskriftet Standart (Rannes, 1992) hypede jeg den arabiske roman for denne egenskab, i artiklen i Vinduet (Rannes, 2002) indså jeg, at når selv professionelle læsere (anmeldere) ikke kan "genkende" og værdsætte denne kvalitet hos Nobelprisvindende Naguib Mahfouz, er der ikke noget at gøre. Den arabiske romans ikkediskursive fortælleforløb var både romanens fornyende egenart og dens akilleshæl. Anmelderne fik (på vegne af de øvrige læsere) ikke, hvad de kom efter - en fortløbende fortælling - og fandt bogen for kedelig.

Det er genistregen i Yacoubians hus, at den overskrider de begrænsninger, som dens arabiske romanform umiddelbart sætter op. Forfatteren al-Aswany lægger den brede kollektivromans mange forskellige historier perfekt side om side (nærmest sideordnede, som sætninger i det arabiske sprog), således at selv den alvidende fortæller, en slags medbeboer i Yacoubians hus, har en udsigelseshistorie, der er en hel fortælling i sig selv og synes at ligge parallelt med de øvrige historier. Uden at bryde med et af kollektivromanens grundprincipper, at alle historier er lige vigtige, lader al-Aswany én historie (faktisk to) trække romanen episk fremad. Da den grådige skjorteskrædder (som en anden olympisk fortæller) sørger for, at den unge rebelske Busayna bliver en del af den ældre levemand Zakis husholdning, etableres den eneste handlingsmæssige forbindelse mellem romanens mange ellers helt adskilte historier.

Dette ene centrale handlingselement, der i sig selv kan holde læserens interesse for fortællingen fangen - vil Busayna forråde Zaki for penge, eller hvordan vil det dog gå? - er lagt hen over romanens 1. og 2. del, hvor også alle de andre historiers skæbner udspændes og besegles. Selvom de forskellige personers skæbner er helt forskellige og uafhængige (der er ikke noget handlingsmæssigt skæbnefællesskab, som det ofte er tilfældet for kollektivromaner i den europæiske tradition), bliver skæbnerne via den fortælletekniske parallelitet bundet op på Busayna-Zaki-historien. Fortælleteknisk formår Alaa al-Aswany i sin arabiske kollektivroman, hvad den arabiske kollektivroman traditionelt ikke har formået: at læserne ubevidst oplever, at alle historierne er del af én og samme historie og fremstår som ét langt handlingsforløb. Han formår at holde fortællingen, det episke, i gang i sin arabisk roman. For læserne synes det at gøre den helt store forskel, i alt fald hvis 90.000 danske læsere ikke tager fejl.

For de danske anmeldere var der heller ikke meget at tage fejl af. Den første danske anmeldelse af Yacoubians hus stod under overskriften "Morgenlandets undergang" at læse i Politiken den 16. oktober 2007. Hos anmelderen Bjørn Bredal er der ingen tvivl om, at fortælleforløbet fungerer: "Yacoubians hus er en roman, som ingen elsker af romaner vil kunne lægge fra sig uden at elske romaner endnu højere, og 
som ingen elsker af Egypten vil kunne læse uden gys og tårer." Hovedpersonernes og deres gerningers troværdighed og forfatterens kærlighed til sine figurer er ifølge Bredal en af kvaliteterne i romanen, som også "stråler i alle farver, den myldrer med fascinerende Kairo-boere [...] og midt i al sin gru har den en charme og naiv ligefremhed, som ikke er til at stå for." Ellers er konklusionen "at Aswany skriver på et niveau, som hæver ham op i verdenslitteraturen."

Med udgangspunkt i, at "man skal være en meget stor forfatter for at beskrive den Kairotiske (sic) virkelighed, som den ser ud i dag" er Lars Bonnevie i sin grundige anmeldelse i Weekendavisen (26. oktober 2007) ikke i tvivl om, at "denne kollektivroman om beboerne i omtalte hus rykker", selvom han (der er kender af arabisk prosalitteratur) mener, at kollektivromanformen bevirker, "at mekanikken ofte bliver for synlig, når personer skal føres ind og ud af scenen". Bonnevie er i det hele taget velargumenteret kritisk og påpeger, at "som administrator af rollefordelingen virker al-Aswany ikke ganske sikker på hånden", og at "den stil, romanen fortælles i, [virker] jævn, undertiden overfladisk". Samtidig er han ikke blind for, at et par aspekter ved romanen "også bør skaffe den et dansk publikum": bl.a. dens "politiske frisprog" og "et langt mere differentieret syn på den ægyptiske storbykvinde, nemlig som den sanselige, nydende, underfundigt selvstændige dame, der bruger manden lige så meget for sin fornøjelses skyld, som han bruger hende". Dog er Bonnevies konklusion: "al-Aswany kommer på ingen måde op på siden af en anden Kairo-forfatter, Naguib Mahfouz".

I Berlingske Tidende (3. november 2007) hengiver anmelder Lars Handesten sig også betingelsesløst til Yacoubians hus, som man bør læse af denne gode og indiskutable grund: "Det hører til sjældenhederne, at man på vores breddegrader kan komme til at læse en egyptisk roman." Romanen tildeles 5 af 6 stjerner, måske af følgende overfladiske grunde: Den "giver et spændende og interessant blik ind i en verden, som vi ikke er særligt bekendt med, nemlig den arabiske", man får "et bredt billede af livet i Cairo i tiden omkring Kuwait-krigen", den "politisk tegner [...] et billede af ekstrem og ødelæggende korruption" eller den "rummer et sandt frisind, hvad det erotiske angår. Det er ikke mindst det, der bereder læseren en stærk og fin oplevelse".

Generelt er de danske anmeldere faldet pladask for Yacoubians hus. Selv om der deles roser og stjerner ud til romanen, vil man lede forgæves efter egentlige, saglige argumenter for bogens litterære kvaliteter. Der savnes tilkendegivelser af det unikke $i$, at denne egyptiske roman pludselig overskrider de barrierer, som ellers har holdt arabisk litteratur væk fra bl.a. det danske litterære marked, og især er det påfaldende, at anmelderne i 2007 er dårligere til at redegøre for Yacoubians hus' kvaliteter, end de i 1989-1990 var til at redegøre for Midaqgydens mangler. ${ }^{10}$ En mulig forklaring herpå er, at Yacoubians hus er så vellykket et stykke (verdens-?) litteratur, at læserne, selv de professionelle - anmelderne - grundlæggende ikke hæfter sig ved, at der er tale om en arabisk roman.

Fra den danske udgiver af Yacoubians hus, Hr. Ferdinand Forlaget, forlyder det, at man blev opmærksom på Alaa al-Aswanys bog efter, at den var udgivet på engelsk i Kairo, men før den gik hen og blev en international bestseller. Da bogen udkom 
på dansk i efteråret 2007, gav de gode danske anmeldelser overraskende fokus på bogen. Bogens gode ry synes at være gået fra mund til mund, således at bogen har nået de utroligt høje salgstal i Danmark, uden at der ligger de helt store reklamebudgetter bag. ${ }^{\text {II }}$

Da Alaa al-Aswanys roman عمارة يعقوبيان (Imārat Ya'qūbīān, Yacoubians hus) i 2002 udkom på det lille egyptiske forlag Merit, lignede den ikke umiddelbart en international - eller bare en arabisk - bestseller. Al-Aswanys tre første forsøg med fiktion var blevet afvist af det store nationale egyptiske forlag GEBO (General Egyption Book Organisation), og han var på nippet til at opgive sin forfatterkarriere. Men det første oplag af Yacoubians hus var udsolgt på fire uger. Siden er bogen, der i perioden 2002-2005 var den bedst sælgende arabiske roman, trykt i 250.000 eksemplarer, et oplag som f.eks. ingen af Naguib Mahfouz' bøger nogensinde udkom $\mathrm{i}$ - arabiske standardoplag er normalt 3.000. ${ }^{\mathrm{I}}$

En bogs meget store succes i hjemlandet er ikke - slet ikke i de arabiske lande ensbetydende med en lignende succes på internationalt plan. Efter succesen i den arabiske verden blev Yacoubians hus i 2004 oversat og udgivet på engelsk på det anerkendte Kairo-baserede forlag "The American University in Cairo Press". Nok er AUC Press udgiver af alle engelske oversættelser af Naguib Mahfouz' bøger, men deri er ingen garanti for et internationalt gennembrud og da slet ikke international bestsellerstatus. Forlagets omfangsrige katalog (og bagkatalog) indeholder masser af oversat nyere og klassisk egyptisk skønlitteratur, som man må formode aldrig var udkommet på engelsk uden for AUC Press' regi. I 2006 blev AUC Press' engelske version af Yacoubians hus solgt til det verdensomspændende britiske forlag HarperCollins. Men spørgsmålet er, om HarperCollins' litterære agenter mon bedre end folkene på Hr. Ferdinand Forlaget vidste, hvad det var, de købte af AUC Press? Det tror jeg ikke, de gjorde. En nærlæsning af den 'fysiske' bog Yacoubians hus' udviklingshistorie vil kunne vise det.

Jeg har ikke haft lejlighed til at se Yacoubians hus i den original Merit-udgave, men en (senere?) arabisk Madbouli-udgave ligner den arabiske bog, den er. Forsiden er holdt i karakteristisk egyptiske støvede bogfarver (bøgerne bliver støvede i arabiske boghandler alligevel) og prydes af et flereetagers hus (virkelighedens Yacoubians hus?). Billedet er sløret og ses gennem et nøglehul, der slår bogens tone an som en slags afslørende nøgle(huls)roman. Den første engelske udgave (fra AUC Press) tager hul på internationaliseringen af bogen. Forsiden viser noget, som alle egyptere, men ikke mange udlændinge kender: kulørt vasketøj, der hænger til tørre på et fladt Kairo-tag. Både denne (social-)realistiske forside og forsiderne på de to følgende engelske udgaver henvender sig først og fremmest til et publikum, der er interesseret i arabisk/egyptisk kultur. Forsiden på Harper Perennial paperbackudgaven (august 2006) viser en mørkklædt mand og en ærbar-islamisk påklædt kvinde stå ved Nilen i Kairo. Trods topteksten "International Bestseller" på Fourth Estate hardback-udgaven (februar 2007) er det ikke det, som forsidens egyptiske storbybondekone udstråler. Hun er omgivet af farverige etniske stoffer i et vindue, der ikke sidder i "et enestående smukt byggeri - ti højloftede etager i højklassisk, europæisk stil, med balkoner, der var pyntet med græske ansigter skåret ud i sten" (al-Aswany 2007, 17). Træskodderne og den gul-pudsede væg sender tankerne i ret- 
ning af en af Kairoforstædernes mange primitive boligkarréer.

Den seneste engelske udgave af Yacoubians hus (Harper Perennial paperback, september 2007) ligner det, den er. Under "The international number one bestseller" ses en farverig og charmerende chick lit-agtig tegning af en etageejendom med silhouet-fyldte vinduer og flagrende vasketøj på det flade tag. Al realisme er her vasket ud af etniciteten, der nu er ren staffage.

Forsiden på den danske udgave af Yacoubians hus (efteråret 2007) kan passende føjes ind i denne forsideanalyse. Her er ingen realisme, men fuldt blus på etniciteten. En rød trædør, indfattet i en smuk islamisk døråbning med hvidmalet stukkant møder læseren. Døren er placeret i en ellers bar facade, angiveligt et hus (en moske?) fra det islamiske (dvs. middelalderlige) Kairo. Den islamisk-etniske æstetiske linie er fulgt til mindste detalje på hardbackudgavens smudsomslag. Her er arabesk-lignende 'præg' på ryg og flapper, der lækkert er kantet med dekorative bånd med udsnit af orientalske flisemosaikker. I forlængelse heraf er det interessant, at i Sverige, hvor der er en lang seriøs litterær tradition for at udgive oversat arabisk litteratur, er forsiden på Albert Bonniers Förlags hardbackudgave af Yacoubians hus (Yacoubians hus, 2008) det realistiske vasketøjsfoto fra den engelske Kairoudgave (2004), mens forlagets paperback-udgave har chick lit-forsiden fra den seneste Harper-udgave. Forsideanalysen viser "the making" af en international bestseller. Den viser, hvordan en arabisk romansucces overraskende folder sig ud, først nationalt, siden internationalt og bliver en international bestseller. Forsidernes signalforskydning viser alle trin i den udvikling, fra afslørende egyptisk nøglehulsroman, via en oversat realistisk egyptisk roman for de (vi) få, der synes om den slags, over en insisterende etnisk "international bestseller" til en mere anonym "international number one bestseller". Men det viser også et helt nyt gennembrud for arabisk litteratur, som ingen har kunnet forudse.

Alaa al-Aswany fortæller i et interview, at Yacoubians hus pr. september 2008 har solgt næsten én million eksemplarer på 22 forskellige sprog. ${ }^{13}$ Romanens bestsellerstatus er uomtvistelig og ikke bare et postulat på forsiden af de seneste par engelsksprogede udgaver. Alene salgstallene i Danmark er helt ekstraordinære. I forsøget på at forklare bogens internationale gennembrud og på baggrund af det at prøve at forstå, om den arabiske roman endelig har fundet en lige, litterær vej til danske læsere, er der flere forskellige faktorer, der kan trækkes frem.

Den første faktor er bogens indhold. Der er ingen tvivl om, at en af grundene til, at netop denne roman er blevet en international bestseller, er samme grund som gjorde den til en bestseller-succes i den arabiske verden. Romanen omhandler en række aktuelle og væsentlige emner - korruption, politivold, seksualitet, homoseksualitet, fundamentalisme m.fl. - som interesserer både arabiske og ikke-arabiske læsere. Men jeg mener ikke, at det er forklaring nok. Andre arabiske forfattere har før taget kontroversielle emner op i deres romaner. F.eks. førnævnte Naguib Mahfouz, hvis romaner i flere omgange er blevet forbudt i flere arabiske lande, og som i 1994 (som 84-årig) blev knivangrebet og alvorligt såret af en islamisk fundamentalist. Mahfouz har som den eneste arabiske forfatter modtaget Nobelprisen i litteratur (1988), og dette vigtige arabiske forfatterskab fik derved en international 
bevågenhed, som intet arabisk forfatterskab havde fået før. Men at tale om et internationalt gennembrud eller bestsellerstatus i Mahfouz' tilfælde vil ikke være korrekt.

En anden betydende faktor kunne være en slags post-9/11-islamisk-stress, som har ramt os i den vestlige verden. Altså en lidelse, der betyder, at kunstneriske og kulturelle udtryk, der kommer fra den islamiske verden, og som ikke ensidigt handler om religiøs fundamentalisme, terror, had til USA og Vesten, Muhammed-tegninger og afbrænding af Dannebrog, modtages velvilligt af et overfølsomt, men åbent interkulturelt sind. Andre væsentlige litterære og ikke-litterære udgivelser synes at have nået os på den konto uden dog at nå bestseller-oplagstal.

Jeg har ovenfor lagt en del vægt på de litterære, fortælletekniske faktorer i Yacoubians hus. Ved den fortælletekniske analyse af romanen mener jeg at have vist, at det simpelthen er lykkedes for Alaa al-Aswany at skrive en arabisk roman, som også ikke-arabiske læsere kan læse - og vil læse. Men det er måske endda et større gennembrud end det. Meget tyder på, at den succes, som Alaa al-Aswanys roman har opnået i Egypten og andre arabiske lande, også betegner et større gennembrud for den egyptiske forlagsverden og dermed for læserne i den arabiske verden. ${ }^{14}$ Tidligere var en bestseller i den arabiske verden en bog, der solgte over 5.000 eksemplarer. Det er der lavet om på nu. Tiden og litteraturhistorien vil måske endda vise, at der med Alaa al-Aswanys roman Yacoubians hus er tale om et helt nyt arabisk prosagennembrud.

\section{Noter}

I Citeret fra min egen oversættelse af det oprindeligt engelske brev. Brevet blev sendt til al-Aswany via hans nordiske (skandinaviske) agent, men om han nogensinde personlig så mit brev, er jeg ikke klar over. Jeg fik dog det svar fra agenten, at et besøg på Hald Hovedgaard ikke kunne passe ind $\mathrm{i}$ al-Aswanys travle kalender.

2 Fra det danske forlag Hr. Ferdinand forlyder det, at tallet nu er 90.000.

3 Jf. bestsellerlisten "Skønlitteratur" i Bjervig 2009: 29.

4 Smukke før-islamiske digte findes på dansk i Sonne 1969.

5 Marzari 2006 argumenterer for dette og viser på s. 50-56, hvordan et uddrag af en litterær tekst af Naguib Mahfouz, som udelukkende har sideordnet sætningskonstruktion i den engelsk oversættelse, må skrives om til underordnet sætningskonstruktion for at give mening for læseren. Tilsvarende udgjorde det arabiske sprogs 'diglossia' - eksistensen af på den ene side et skriftligt arabisk (al-fusha) og på den anden et talt arabisk (al-'ammiya) - i alt fald i den moderne arabiske prosas første år, også et grundlæggende sprogproblem, der skulle overkommes: kunne man skrive på al-fusha, når virkeligheden foregik på al-'ammiya? Dette problem behandles i Elisabeth Moestrups artikel i nærværende nummer af Passage.

6 Se f.eks. Manzalaoui 1986.

7 Oversatte eksempler på arabiske romaner, hvor den samme handling fortælles fra flere forskellige synsvinkler, er Fathi Ghanems al-rajul alladhi faqada zillahu (1966, Eng. The Man Who Lost His Shadow, 1980) og Naguib Mahfouz' Miramar (1967, da. Pension Miramar, 1989).

8 På dansk er Mahfouz 1989 et godt eksempel på en sådan kollektivroman.

9 I den arabiske originaludgave starter 2. del på s. 149.

Io Jf. Rannes 1992 og Rannes 2002. 
II Jf. telefonisk samtale med forlægger Snæbjörn Arngrímsson fra Hr. Ferdinand Forlaget.

I2 Siden 2007 er Yacoubians hus kun overgået på bestsellerlisten af al-Aswanys nyeste roman Chicago jf. al-Aswany 2008: 54.

I3 Jf. al-Aswany 2008: 54.

I4 F.eks. i "Egyptian readers under the microscope".

\section{Litteraturliste}

al-Aswany, Alaa (2007): Yacoubians hus, København: Hr. Ferdinand.

al-Aswany, Alaa (2008): "Yacoubians hus og Chicago - samtale mellem Alaa al-Aswany og Jakob Skovgaard-Petersen", i Bogens Verden nr. 4.

Bjervig, Niels (2009): "Bestsellerlisten - skønlitteratur" i Bogmarkedet 11.

Mahfouz, Naguib (1989): Midaqgyden, København, Holkenfeldt.

Manzalaoui, Mahmond (ed.) (1986): Arabic Short Stories, 1945-1965, Cairo: The American University in Cairo Press.

Marzari, Robert (2006): Arabic in Chains: Structural Problems and Artificial Barriers, Broschur: Verlag Hans Schiler.

Rannes, Peter Q. (1992): “Den arabiske litteratur - endnu en antologi-litteratur”, i Litteraturmagasinet Standart nr. 1.

Rannes, Peter Q. (2002): “Tilfældet Naguib Mahfouz - eller gensyn med den arabiske litteratur”, i Vinduet nr. 1-2.

Sonne, Jørgen (red.) (1968): 8 arabiske digtere, København: Rhodos.

Watt, Ian (1972): The Rise of the Novel: Studies in Defoe, Richardson and Fielding, London, Chatto \& Windus.

Wulff, Ellen (overs.) (2006): Koranen i ny dansk oversættelse, København: Vandkunsten. 